\title{
Determination of Concrete Vault Thickness of Near Surface Disposal for Radioactive Waste at Serpong Nuclear Area
}

\author{
Sucipta*, Suhartono \\ Center for Radioactive Waste Technology, BATAN, Kawasan PUSPIPTEK Serpong, Tangerang Selatan, Indonesia
}

\begin{tabular}{l}
\hline INFORMASI ARTIKEL \\
\hline Riwayat Artikel: \\
Diterima: \\
25 Agustus 2017 \\
Diterima dalam bentuk revisi: \\
28 Februari 2018 \\
Disetujui: \\
3 April 2018 \\
\hline
\end{tabular}

\section{Keywords:}

thickness

vault

disposal

radioactive waste

\begin{abstract}
DETERMINATION OF CONCRETE VAULT THICKNESS OF NEAR SURFACE DISPOSAL FOR RADIOACTIVE WASTE AT SERPONG NUCLEAR AREA. In orderto fulfill the need of disposal for radioactive waste from small-scale nuclear power plant (NPP) operations, research, medical and industrial activities, it is necessary to prepare the near surface disposal facility (NSD). The NSD facility is also to support and complement the national facility of radioactive waste management services in Indonesia. Based on this reason BATAN will build a demonstration disposal facility in Serpong Nuclear Area (SNA). Demonstration disposal that will be built is Near Surface Disposal (NSD) type. Engineered vault for NSD is reinforced concrete. The calculations for determining the thickness of NSD concrete vault is based on the conceptual design as the result of the placement optimization of demonstration disposal that takes into account the inventory of radioactive waste and environmental geology conditions of the site at Serpong Nuclear Area. The thickness of the vault in this paper is focused on its ability to withstand radiation from stored waste so that workers or people near the disposal facility is safe with maximum radiation dose limit rate of $0.3 \mu \mathrm{Sv} / \mathrm{h}$. The calculation is performed with the aid of MicroShield 7:02 and Rad Pro Calculator Version 3:26 software. Based on the results of calculation, the dose rate at the outer surface of the vault should be $0.3 \mu \mathrm{Sv} / \mathrm{h}$, so it's required walls made of concrete with density of $2.35 \mathrm{~g} / \mathrm{cm}^{3}$ and the thickness is $62.8 \mathrm{~cm}$.
\end{abstract}

\begin{abstract}
ABSTRAK
PENENTUAN TEBAL BETON VAULT PENYIMPANAN LESTARI LIMBAH RADIOAKTIF TIPE NEAR SURFACE DISPOSAL. Sebagai langkah antisipasi untuk pemenuhan kebutuhan penyimpanan lestari limbah radioaktif dari operasional Pembangkit Listrik Tenaga Nuklir (PLTN) skala kecil (Reaktor Daya Eksperimental $=\mathrm{RDE})$, kegiatan riset, medis dan industri maka perlu dipersiapkan penyediaan fasilitas near surface disposal (NSD), yang juga sekaligus untuk melengkapi fasilitas nasional pelayanan pengelolaan limbah radioaktif di Indonesia. Dengan alasan tersebut maka BATAN akan membangun fasilitas disposal demo di Kawasan Nuklir Serpong (KNS). Penyimpanan lestari demo yang akan dibangun adalah tipe Near Surface Disposal (NSD). Engineered vault untuk NSD berupa dinding dari beton bertulang (reinforced concrete vault). Perhitungan untuk penentuan tebal beton dinding vault fasilitas NSD dilakukan berdasarkan konsep desain hasil optimasi penempatan penyimpanan lestari demo yang mempertimbangkan inventori limbah radioaktif dan kondisi geologi lingkungan tapak Kawasan Nuklir Serpong. Perhitungan ketebalan dinding vault dalam makalah ini difokuskan pada kemampuannya untuk menahan radiasi dari limbah yang disimpan agar supaya pekerja atau masyarakat yang berada di sekitar fasilitas penyimpanan lestari selamat dari bahaya radiasi yang batas maksimum laju dosisnya $0,3 \mu \mathrm{Sv} / \mathrm{jam}$. Perhitungan dilakukan dengan bantuan perangkat lunak (software) MicroShield 7.02 dan Rad Pro Calculator Version 3.26. Dari hasil perhitungan agar laju dosis di permukaan luar dinding vault menjadi $0,3 \mu \mathrm{Sv} / \mathrm{jam}$, diperlukan dinding yang terbuat dari beton dengan densitas $2.35 \mathrm{~g} / \mathrm{cm}^{3}$ setebal $62.8 \mathrm{~cm}$.

Kata kunci : ketebalan, vault, penyimpanan limbah lestari, limbah radioaktif
\end{abstract}

\section{INTRODUCTION}

As an anticipation step to fulfill the need of disposal for radioactive waste from smallscale nuclear power plant operations, research, medical and industrial activities, it is necessary to prepare the near surface disposal facility (NSD). The NSD facility is also to complement the national facility of radioactive waste management services in Indonesia.
Most of the radioactive waste temporarily stored in interim storage (IS) of Center for Radioactive Waste Technology (CRWT) - BATAN is a low-intermediate level. In order to support and complement the radioactive waste management facilities in Indonesia, BATAN will build and operate the demonstration disposal facility in Serpong Nuclear Area (SNA). Demonstration disposal that will be built is Near Surface Disposal (NSD) type. 
The basic principle of disposal is to limit the radiation dose and risk from disposal activities in accordance with the principle of ALARA (As Low As Reasonably Achievable). All types of disposal in general have the same goal, which is the ability of containment against the stored radioactive waste. Generally, the purpose of disposal is to accommodate radioactive waste; isolate radioactive waste from the biosphere, including reducing the consequences of intrusion into radioactive waste by humans; deter, reduce and delay the migration of radionuclides to the biosphere; and to assure that the magnitude of the possible migration of radionuclides from the disposal facility to the biosphere are still in the acceptable limits[1].

The purpose of this study is to calculate or determine the minimum wall thickness in the form of reinforced concrete vault in order to fulfill the function as a barrier to radiation from radioactive waste stored in it, so as to meet the conditions required in BAPETEN Chairman Regulation No. 4 Year 2013[2]. With the design of the vault wall thickness which meet these conditions will also be met the safety aspect of workers and the public.

\section{DESCRIPTION OF NSD FACILITY}

The basic principle of disposal is that the disposal facility is located, designed, constructed, operated and closed in such a way that the workers, communities, and the environment are protected from radiological hazard[3]. In preparing the design of disposal, the dimensions of the waste package and building dimensions of disposal facility must be prepared. Size, weight and amount of waste to be placed in the disposal should have been taken into account. To avoid subsidence, foundation of the disposal should be able to support the load of the overall disposal system. The site of disposal will be not only used as a waste disposal site alone, but need to be equiped for a variety of supporting facilities to complete the disposal operations [3].
In accordance to the result of emplacement optimization of demonstration disposal based on the environmental geology aspect at SNA, the plan of construction of disposal facility area is $1,197.16 \mathrm{~m}^{2}$ with a size of $34.6 \mathrm{~m} \times 34.6 \mathrm{~m}[4]$. Engineered vault for NSD is reinforced concrete vault type. Vault will be built with a depth of $2 \mathrm{~m}$ and the foundations of buildings located $4 \mathrm{~m}$ above the highest ground water level. Vault is divided into two twins compartments which separated by reinforced concrete wall. The volume of each vault space is $594 \mathrm{~m}^{3}$ with length of 18 $\mathrm{m}$, width of $6 \mathrm{~m}$ and depth of $5.5 \mathrm{~m}$. Compartment on the right side is to dispose of the waste packaged in a 200 liter drum with the drum-dimension is $85 \mathrm{~cm}$ height and 60 $\mathrm{cm}$ diameter, with the weight about 0.486 ton. Meanwhile, the left side compartment is dedicated for the waste packaged in the concrete shell 950 liter with dimension is 1.4 $\mathrm{m}$ high and $1.3 \mathrm{~m}$ in diameter with weight about 6.4 ton. The right side compartment for 200 liter drums arranged in modules with 15 line, 15 row, and 3 stack, so that a single module can accommodate 675 drums of 200 liters. The left side compartment is for concrete shell of 950 liters will be compiled into a 6 row, 6 line, and 2 stack, so that a single module can accommodate 72 pieces of the concrete shell. As an illustration, layout and cross section of NSD facility can be seen in Figures 1 and 2.

The vault has a function as main buffer of the disposal system. In addition, it is also serves as the main confinement of disposal system, i.e. as a barrier to radiation from radioactive waste and as a barrier (vault and bottom cover) of radionuclides released from radioactive waste packages into the environment. If the function is fail, it will be indicated by two (2) terms, namely the increase of radiation exposure and release of radionuclides[5]. The main principle of radiation protection is barrier (shielding), distance, and time constraints. Vault has one function for the principles of radiation protection, namely as a radiation shield. It really depends on the selection of materials which have a half value layer that is sufficient to withstand the radiation. 


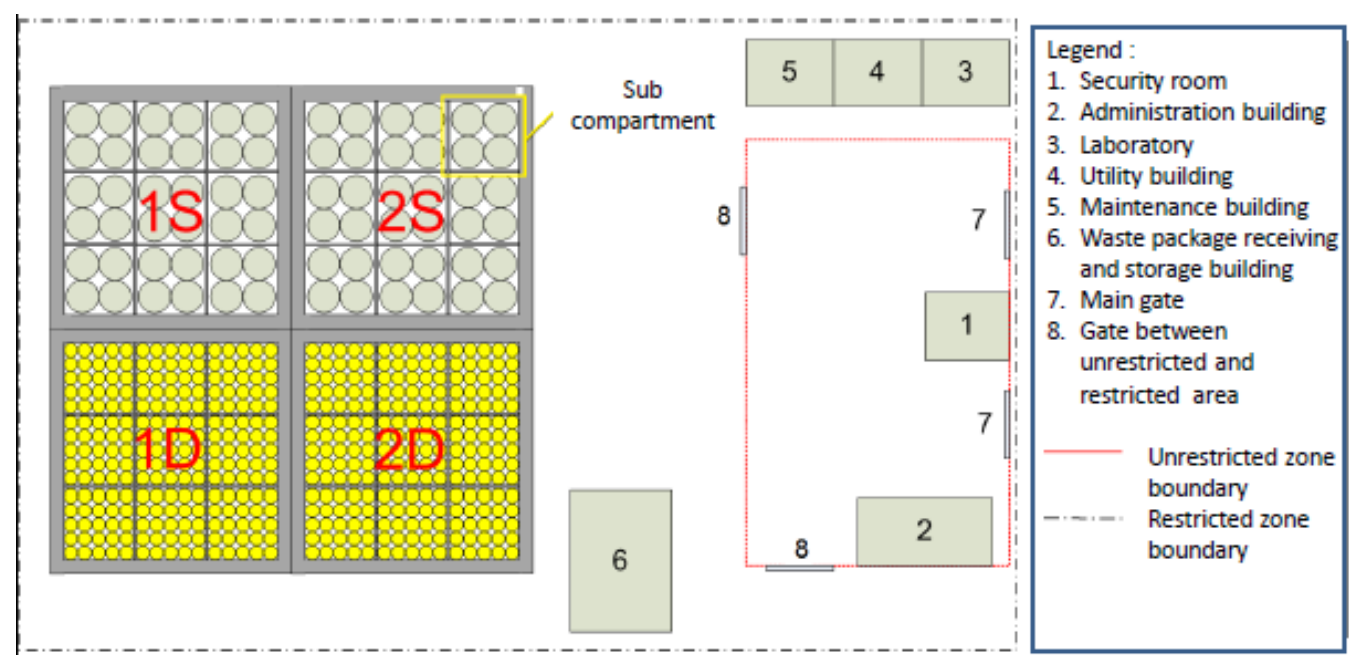

Figure 1. Layout of Near Surface Disposal Facility at Nuclear Serpong Area Site[4].

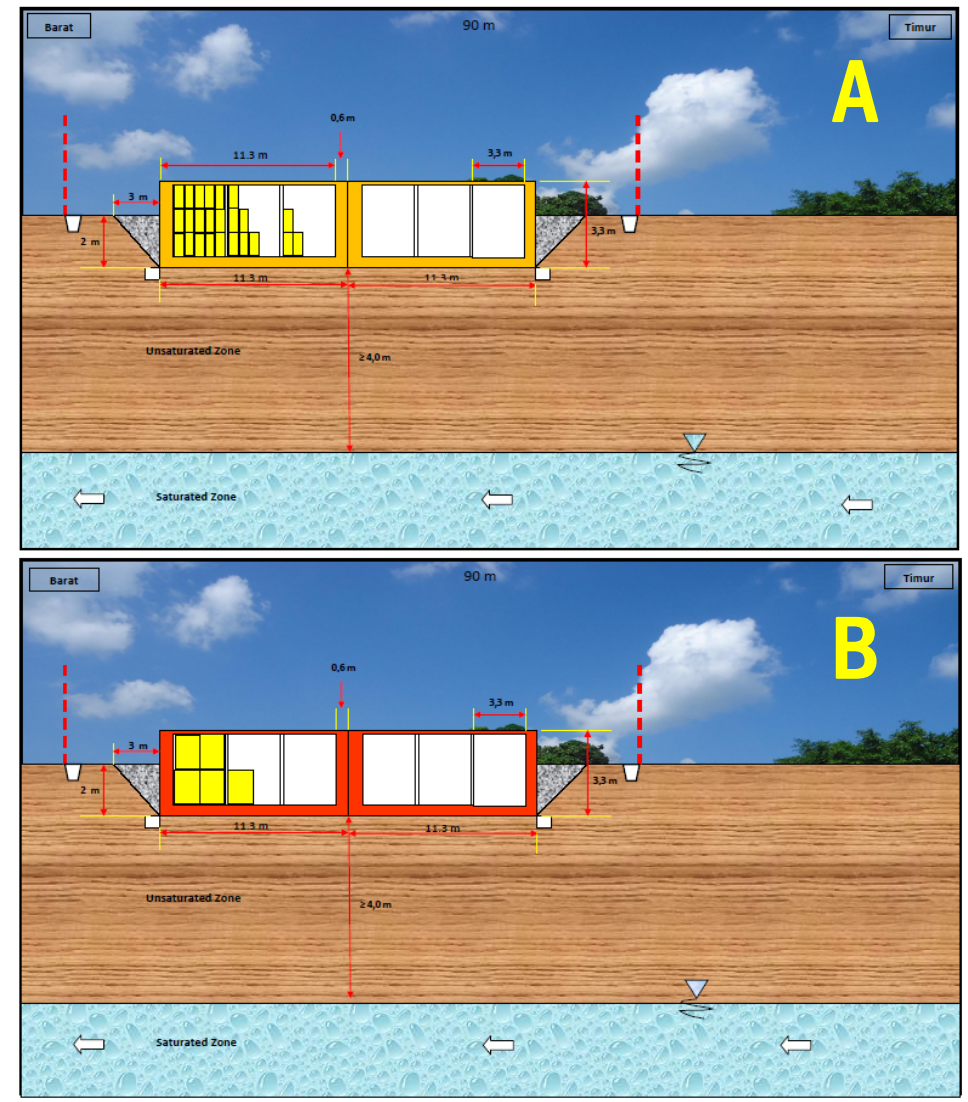

Figure 2. Cross Section of Waste Emplacement of NSD Facility[4]. (A) Cross Section through The Drum Package Zone West-East Direction. (B) Cross Section through The Concrete Shell Package Zone West-East Direction.

While its function as confinement is highly depended on the quality and homogeneity of the materials composition in order to withstand the external hazard (geotechnical and hydrological/ hydrogeological) and climate of the site.

In an effort to control the risk of radiation exposure outside the vault, so at the design phase, the inventory of radioactive waste that will be stored in the NSD, it radionuclide, activity, radiation exposure and the amount or volume, should be known. By knowing the waste inventory, the design of vault can be determined, such a material with a half value layer and adequate thickness. Recommended for the design vault is reinforced concrete K350. The function of this concrete both as a radiation shield, and also 
serves as a reinforcing structure in order for optimization of disposal placement at SNA site.

As a radiation shield, confinement of radionuclides, the determination of vault wall thickness must consider site conditions (carrying capacity), precipitation, relatively shallow ground water table and the potential for ground movement. Calculation or determination of the thickness of the vault wall discussed in this paper is focused on its ability to withstand radiation from waste stored so that workers or peoples who live in or around the disposal facility are safe from the radiation hazard. The limit of radiation amount received by workers (average effective dose) is $20 \mathrm{mSv} / \mathrm{year}$ and for the public is $1 \mathrm{mSv} / \mathrm{year}$ and the criteria of the radiation area of very low dose rate is 0.3 $\mu \mathrm{Sv} / \mathrm{h}[2]$. A study related to vault disposal facility has been done by a previous researcher[6]. Underground concrete vault is used to store contaminated material as hazardous waste and radioactive waste in the long term period. The protection system for the public from waste contamination in the long term period is immobilizing the waste using concrete vault.

Parameters to be evaluated for the design of the concrete vault covers the properties of soil layers around the vault, vault size, slope and magnitude of the degradation of the concrete vault to variations in infiltration rate[6].

Bulgaria plans to build near surface disposal facility with concrete vault type for low-intermediate level radioactive waste is known as National Disposal Facility (NDF). NDF design includes additional vault coatings in the form of filler material engineering (engineered fill) called loess-cement cushion. Loess-cement cushion is expected to increase the stability of geotechnical and increase the height of NDF foundation position, adding the thickness of the unsaturated zone of groundwater, as well as a chemical barrier to absorb the radionuclides drops down towards the ground water zone[7]. Aspect of cushion studied is the design, function and construction that are an integral component in the site safety concept.
Degradation of waste and the confinement materials from the effects of radiation shall be considered for the disposal system. Intensive radiation exposure causes the degradation of the structure and strength of the materials that could lead to failure. The effects of radiation from nuclear waste disposal in the system include the effect of causing damage to the structure of the atomic structure, thermal effects that cause chemical reactions and changes in morphology, diffusion effects associated with the movement of radionuclides and hydrological effects associated with groundwater movement[8].

\section{METHOD}

Calculation or determination of thickness of the vault concrete wall for NSD facility is based on the conceptual design of demonstration disposal as a result of placement optimization assessment which takes into account the inventory of radioactive waste and the environmental geology conditions of the site at SNA $[9,10]$. The calculation is performed with the MicroShield 7:02 [11] and Rad Pro Calculator Version 3:26 software [12].

The steps of the calculation as follows:

a. Fundamentals of calculation:

The $950 \mathrm{~L}$ concrete shell is designed for cementation of waste with a total activity 1 Ci. Radionuclides significantly dominant in the liquid radioactive waste is $\mathrm{Cs}-137$.

b. The composition and dimensions of the concrete shell 950 liters:

Drum / steel tank on the inside, height 98.5 $\mathrm{cm}$, radius of $53 \mathrm{~cm}$ and $0.3 \mathrm{~cm}$ thick plate and concrete thickness of $13 \mathrm{~cm}$.

c. Configure storage concrete shell containing waste cemented:

As shown at Figure 3, 6 (six) concrete shells are parallel to the $\mathrm{X}$ axis, 2 (two) concrete shell are parallel to the $\mathrm{Y}$ axis, and 6 (six) concrete shell are parallel to the $\mathrm{Z}$ axis. The distance between the outer surface of the concrete shell to vault wall is $5 \mathrm{~cm}$. 


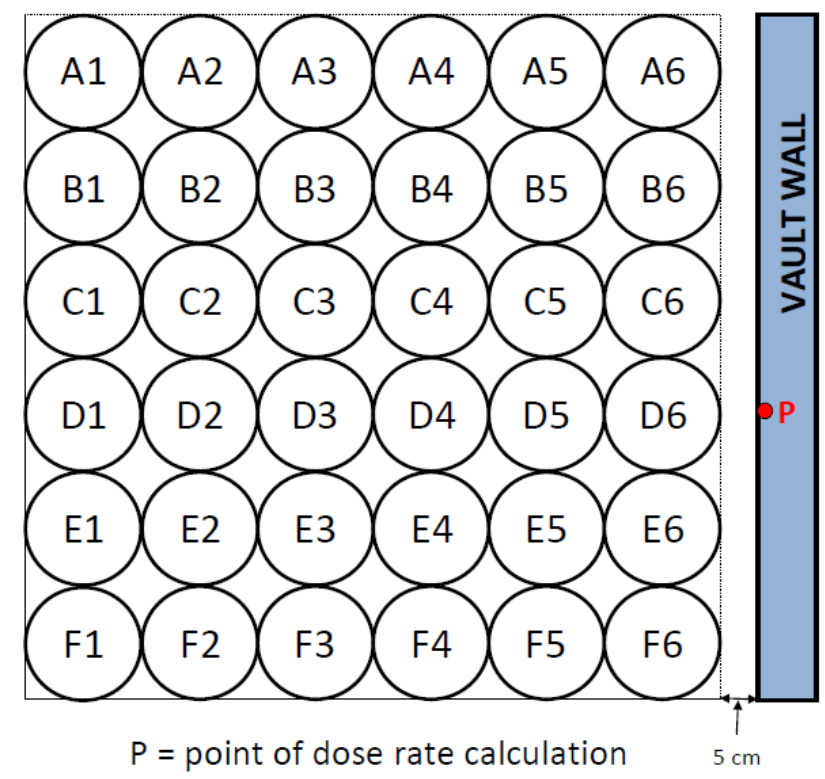

Figure 3. Configuration of Concrete Shell of Radioactive Waste Package on The NSD.

Table 1 Schematic Calculation of Dose Rate Using Microshield 7.02 Software

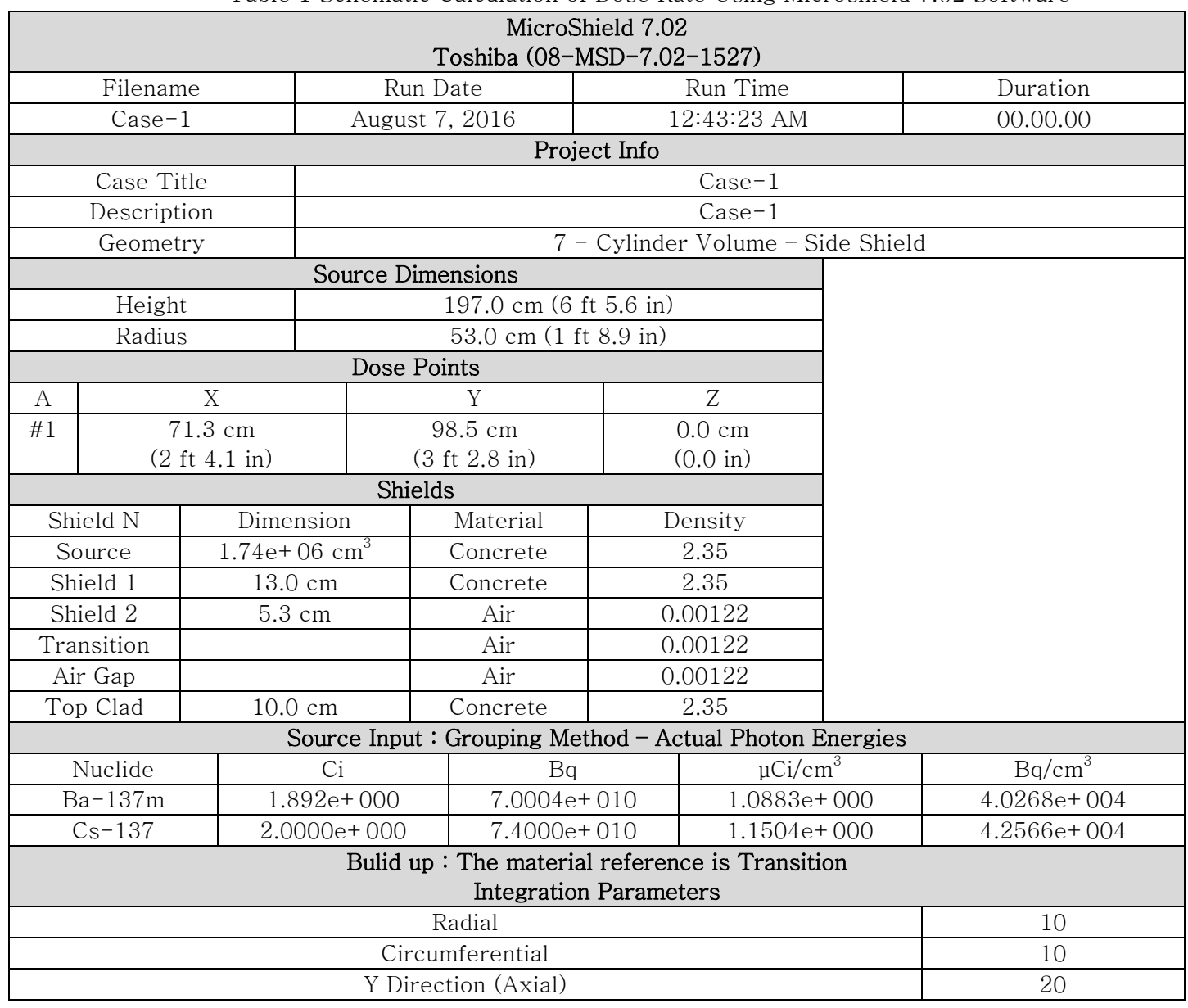


Table 2. Result of Dose Rate Calculation Using Microshield 7.02 Software

\begin{tabular}{|c|c|c|c|c|c|}
\hline $\begin{array}{l}\text { Energy } \\
(\mathrm{MeV})\end{array}$ & $\begin{array}{c}\text { Activity } \\
\text { (Photons/sec) }\end{array}$ & $\begin{array}{l}\text { Fluence Rate } \\
\mathrm{MeV} / \mathrm{cm}^{2} / \mathrm{sec} \\
\text { No Build up }\end{array}$ & $\begin{array}{l}\text { Fluence Rate } \\
\mathrm{MeV} / \mathrm{cm}^{2} / \mathrm{sec} \\
\text { With Build up }\end{array}$ & $\begin{array}{c}\text { Exposure Rate } \\
\text { mR/hr } \\
\text { No Build up }\end{array}$ & $\begin{array}{c}\text { Exposure Rate } \\
\mathrm{mR} / \mathrm{hr} \\
\text { With Build up }\end{array}$ \\
\hline 0.0045 & $7.267 \mathrm{e}+08$ & $5.288 \mathrm{e}-119$ & $6.586 e-25$ & $3.624 e^{-119}$ & $4.514 \mathrm{e}-25$ \\
\hline 0.0318 & $1.449 \mathrm{e}+09$ & $1.055 \mathrm{e}-14$ & $3.565 \mathrm{e}-13$ & $8.788 \mathrm{e}-17$ & $2.970 \mathrm{e}-15$ \\
\hline 0.0322 & $2.674 \mathrm{e}+09$ & $5.254 \mathrm{e}^{-14}$ & $1.839 \mathrm{e}-12$ & $4.229 \mathrm{e}-16$ & $1.480 \mathrm{e}^{-14}$ \\
\hline 0.0364 & $9.731 \mathrm{e}+08$ & $9.882 \mathrm{e}^{-11}$ & $5.118 \mathrm{e}-09$ & $5.615 e-13$ & $2.908 \mathrm{e}-11$ \\
\hline 0.6616 & $6.299 \mathrm{e}+10$ & $1.216 \mathrm{e}+03$ & $1.261 \mathrm{e}+04$ & $2.357 \mathrm{e}+00$ & $2.445 e+01$ \\
\hline Total: & $6.881 \mathrm{e}+10$ & $1.216 \mathrm{e}+03$ & $1.261 \mathrm{e}+04$ & $2.357 \mathrm{e}+00$ & $2.445 \mathrm{e}+01$ \\
\hline
\end{tabular}

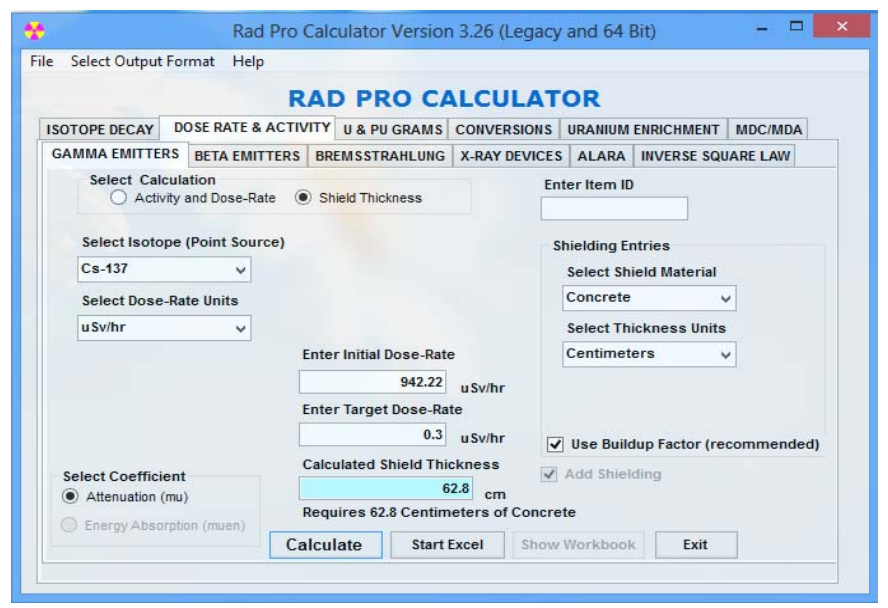

Figure 4. Calculation of Vault Concrete Thickness for NSD using Rad Pro Calculator Version 3.26 software.

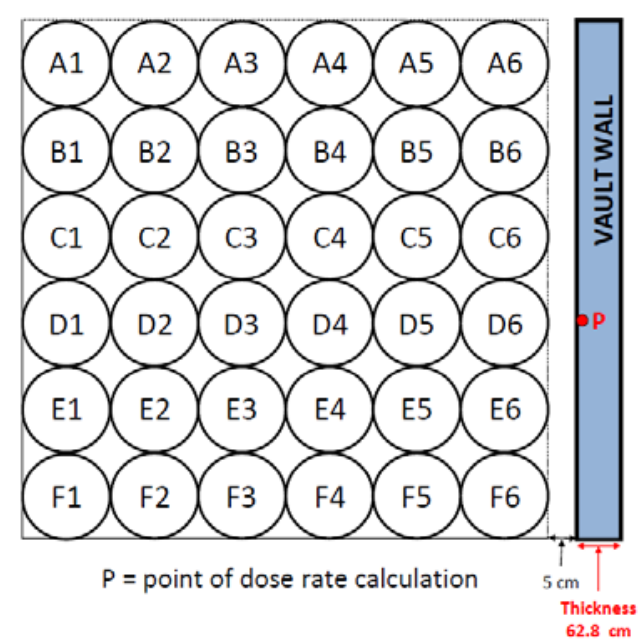

Figure 5. Thickness of NSD Vault.

d. Basic (assumption) calculation:

The 2 pieces pile concrete shell are considered as a single entity, so that every single point of storage configuration of concrete shell (e.g. the configuration point D6) consists of two drums / steel tank containing cemented resin waste. Thus, the high drum / tank equal to $2 \mathrm{x}$ $98.5 \mathrm{~cm}$ (equal to $197 \mathrm{~cm}$ ), fingers drum / tank of $53 \mathrm{~cm}$, a total activity of Cs -137 equal to $2 \times 1 \mathrm{Ci}$ (equal to $2 \mathrm{Ci}$ ). e. Determine the highest dose rate on the $\mathrm{Y}$ axis (vertical axis).

f. Calculation of the dose rate contributions at the point $\mathrm{P}$ of a concrete shell on the specific configuration. Calculations using MicroShield 7:02 software.

g. Calculation of vault thickness for concrete shell storage building. Calculations using Rad Pro Calculator Version 3.26 software. 


\section{RESULTS AND DISCUSSION}

Contributions of dose rate derived from a configuration point D6 with assumption that radiation sources of $\mathrm{Cs}-137$ with activity $2 \mathrm{Ci}$ is uniformly dispersed in a matrix of concrete cylindrical solid with $197 \mathrm{~cm}$ high, $53 \mathrm{~cm}$ radius of the cylinder volume reached $1.74 \mathrm{x}$ $106 \mathrm{~cm}^{3}$. The concrete shield form of $13 \mathrm{~cm}$ thick and space $5.3 \mathrm{~cm}$ consist of air. The measurement point is made in the direction of the $\mathrm{X}$ axis $=71.3 \mathrm{~cm}, 98.5 \mathrm{~cm}=\mathrm{Y}$ axis and $\mathrm{Z}$ axis $=0 \mathrm{~cm}$ (point $\mathrm{P}$ ) as shown in Table 1 .

Calculations using MicroShield 7:02 software shows that the 9501 concrete shell at D6 configuration, contributing dose rate of $2.445 \mathrm{E}+1 \mathrm{mR} / \mathrm{hr}(244.50 \mu \mathrm{Sv} / \mathrm{h})$ at the point $\mathrm{P}$. The calculation results as shown in Table 1 . With the same way, the dose rate contribution of the points at the other configuration can be calculated based on the measurement point $\mathrm{P}$. The results of the calculations are summarized in Appendix 1.

The accumulation dose rate from the entire configuration of the concrete shell at the measurement point $\mathrm{P}$ is at $942.22 \mu \mathrm{Sv} / \mathrm{h}$. This value is used as the basis for calculating the value of the dose rate on the surface of vault. The dose rate on the outside surface of the vault is desired to $0.3 \mu \mathrm{Sv} / \mathrm{h}$ (twice the dose rate of background), in order to meet the criteria of the area with very low radiation.

Calculations using Rad Pro Calculator Version 3:26 software can be seen in Figure 4. Based on the result of these calculation, it can be seen that to arrange the dose rate at the outer surface of the vault wall (become $0.3 \mathrm{\mu Sv} / \mathrm{h}$ ), it's required wall made from concrete with density $2.35 \mathrm{~g} / \mathrm{cm}^{3}$ and thickness about $62.8 \mathrm{~cm}$. Schematically, the illustration of disposal vault wall thickness can be shown in Figure 5. With the thickness of the concrete vault is $62.8 \mathrm{~cm}$, the dose rate at the outside of the vault wall will be $0.3 \mu \mathrm{Sv} / \mathrm{h}$. This condition will meet the criteria of area with very low radiation[5].

In order to complete the safety assessment objective, there are some parameters need to be evaluated from the design of the concrete vault. The parameters needed are the properties of soil layers around the vault and the magnitude of the degradation of the concrete based on the variations of infiltration rate[6]. In addition, it should also need to be studied the effects of radiation from the nuclear waste disposal system includes structural effects, thermal effects, the effects of diffusion and hydrological effects on the strength of the concrete vault in the long term period[8].

\section{CONCLUSION}

Calculation using MicroShield 7:02 software shows that the 9501 concrete shell at the $\mathrm{D} 6$ configuration, contributing dose rate of $2.445 \mathrm{E}+1 \mathrm{mR} / \mathrm{hr}(244.50 \mu \mathrm{Sv} / \mathrm{h})$ at the point $\mathrm{P}$. The dose rate accumulation from the entire configuration of the concrete shell at the measurement point $\mathrm{P}$ is $942.22 \mu \mathrm{Sv} / \mathrm{h}$. Based on the calculation results can be seen that the dose rate at the outer surface of the vault wall of the concrete shell storage building is of 0.3 $\mu \mathrm{Sv} / \mathrm{h}$, required a concrete wall with density $2.35 \mathrm{~g} / \mathrm{cm}^{3}$ with the thickness about $62.8 \mathrm{~cm}$.

\section{ACKNOWLEDGMENT}

Our gratitude goes to the head and staff of $\mathrm{BK} 2 \mathrm{O}$ which has provided the opportunity to use the MicroShield 7:02 and Rad Pro Calculator Version 3:26 software. To the management and staff of BPL we also want to thank you for your help in providing the radioactive waste data.

\section{REFERENCES}

[1]. IAEA, "Disposal of Radioactive Waste”, IAEA SSR 5. Vienna, Austria, 2011.

[2]. BAPETEN, Chairman Regulation No. 4, "Radiation Protection and Safety in Nuclear Energy Utilization”, 2013.

[3]. Sucipta, "Conceptual Design of Demonstration Disposal at Serpong Nuclear Area and Characterization of Selected Site for Radioactive Waste Disposal”, Center for Radioactive Waste Technology-BATAN, Serpong, Indonesia, Technical Document, pp. 20-29, 2013

[4]. Sucipta, "Optimization of the Emplacement of Demonstration Disposal in the Geological Environment at Serpong Nuclear Area", Journal of Waste Management Technology vol. 16 No. 2, pp. 47-64, Dec. 2013. Indonesia. 
[5]. Romli, and Sucipta, "Hazard and Operability Study of Design of Demonstration Disposal for Radioactive Waste at Serpong Nuclear Area", in Proc of National Seminar on Waste Management Technology XIII, Serpong, Indonesia, Sept. 2015, pp. 199-211.

[6]. Rice, R.W. and Walton,J.C., "Design Factors Affecting the Flow of Water Through Below-Ground Concrete Vaults", Journal of Environmental Engineering, Vol. 132, No. 10, pp. 1346-1354. Oct 2006.

[7]. Westermann, G.N, et al. "Design and Construction of a Loess-Cement Cushion as an Integral Component of an SL-LILW Repository", WM2016 Conf, Phoenix, Arizona, USA. March 2016, pp. 1-16.

[8]. Rana, M.A., "High-Level Nuclear Wastes and the Environment: Analyses of Challenges and Engineering Strategies", World Journal of Nuclear Science and Technology, Vol. 2, pp. 89-105. 2012.

[9]. Center for Nuclear Geology Development (PPGN), "Investigation of Engineering Geology and Hydrogeology of Demonstration Disposal Site at Serpong Nuclear Area”, BATAN, Jakarta, Indonesia, Final Report, 2010.

[10]. Sucipta, "Mapping of Environmental Geology of PUSPIPTEK, Serpong and the Surrounding Area as a Host of Demonstration Disposal Site", Journal of Waste Management Technology Vol. 17 No. 2, pp. 31-43, 2014, Indonesia.

[11]. Anonymous, MicroShield User's Manual, Grove Software, Inc., Lynchburg, Virginia USA, 2007.

[12].__, (2016, August 7), RadPro Calculator Version 3.26 Available: www.radprocalculator.com 


\section{Attachment 1}

Contribution of dose rate at each concrete shell configuration based on measurement point $\mathrm{P}$

\begin{tabular}{|c|c|c|c|c|c|c|c|c|}
\hline \multirow{3}{*}{$\begin{array}{c}\text { No } \\
\\
\\
1\end{array}$} & \multirow{3}{*}{$\begin{array}{c}\begin{array}{c}\text { Position } \\
\text { of } \\
\text { concrete } \\
\text { shell } \\
\text { (config- } \\
\text { uration) }\end{array} \\
\text { A6 }\end{array}$} & \multirow{2}{*}{\multicolumn{2}{|c|}{$\begin{array}{l}\text { Length of elbow } \\
\text { side }(\mathrm{cm})\end{array}$}} & \multicolumn{4}{|c|}{ Calculation of concrete shielding and air } & \multirow{3}{*}{$\begin{array}{l}\text { Contribut- } \\
\text { ion of dose } \\
\text { rate }(\mu \mathrm{Sv} / \mathrm{h}) \\
15.78\end{array}$} \\
\hline & & & & \multirow{2}{*}{$\begin{array}{c}\text { Total } \\
\text { distance to } \\
\text { point } \mathrm{P} \\
\text { /oblique } \\
\text { side }(\mathrm{cm}) \\
402.37\end{array}$} & \multirow{2}{*}{$\begin{array}{c}\begin{array}{c}\text { Radius of } \\
\text { concrete }\end{array} \\
\text { as source } \\
(\mathrm{cm})\end{array}$} & \multirow{2}{*}{$\begin{array}{c}\text { Thick- } \\
\text { ness of } \\
\text { concrete } \\
\text { shell as } \\
\text { shielding } \\
\text { (cm)* } \\
13\end{array}$} & \multirow{2}{*}{$\begin{array}{c}\text { Air as } \\
\text { shielding } \\
(\mathrm{cm})\end{array}$} & \\
\hline & & 71.30 & 396 & & & & & \\
\hline 2 & B6 & 71.30 & 264 & 273.46 & 53 & 13 & 207.46 & 33.85 \\
\hline 3 & C6 & 71.30 & 132 & 150.03 & 53 & 13 & 84.03 & 97.22 \\
\hline 4 & D6 & 71.30 & 0 & 71.30 & 53 & 13 & 5.30 & 244.50 \\
\hline 5 & E6 & 71.30 & 132 & 150.03 & 53 & 13 & 84.03 & 97.22 \\
\hline 6 & F6 & 71.30 & 264 & 273.46 & 53 & 13 & 207.46 & 33.85 \\
\hline 7 & A5 & 203.90 & 396 & 445.41 & 53 & 13 & 379.41 & 12.85 \\
\hline 8 & B5 & 203.90 & 264 & 333.57 & 53 & 13 & 267.57 & 22.96 \\
\hline 9 & C5 & 203.90 & 132 & 242.90 & 53 & 13 & 176.90 & 42.40 \\
\hline 10 & D5 & 203.90 & 0 & 203.90 & 53 & 13 & 137.90 & 58.38 \\
\hline 11 & E5 & 203.90 & 132 & 242.90 & 53 & 13 & 176.90 & 42.40 \\
\hline 12 & F5 & 203.90 & 264 & 333.57 & 53 & 13 & 267.57 & 22.96 \\
\hline 13 & A4 & 336.50 & 396 & 519.66 & 53 & 13 & 453.66 & 9.39 \\
\hline 14 & B4 & 336.50 & 264 & 427.70 & 53 & 13 & 361.70 & 13.95 \\
\hline 15 & $\mathrm{C} 4$ & 336.50 & 132 & 361.46 & 53 & 13 & 295.46 & 19.57 \\
\hline 16 & D4 & 336.50 & 0 & 336.50 & 53 & 13 & 270.50 & 22.57 \\
\hline 17 & $\mathrm{E} 4$ & 336.50 & 132 & 361.46 & 53 & 13 & 295.46 & 19.57 \\
\hline 18 & $\mathrm{~F} 4$ & 336.50 & 264 & 427.70 & 53 & 13 & 361.70 & 13.95 \\
\hline 19 & A3 & 469.10 & 396 & 613.90 & 53 & 13 & 547.90 & 6.66 \\
\hline 20 & B3 & 469.10 & 264 & 538.29 & 53 & 13 & 472.29 & 8.73 \\
\hline 21 & C3 & 469.10 & 132 & 487.32 & 53 & 13 & 421.32 & 10.70 \\
\hline 22 & D3 & 469.10 & 0 & 469.10 & 53 & 13 & 403.10 & 11.56 \\
\hline 23 & E3 & 469.10 & 132 & 487.32 & 53 & 13 & 421.32 & 10.70 \\
\hline 24 & F3 & 469.10 & 264 & 538.29 & 53 & 13 & 472.29 & 8.73 \\
\hline 25 & $\mathrm{~A} 2$ & 601.70 & 396 & 720.32 & 53 & 13 & 654.32 & 4.79 \\
\hline 26 & B2 & 601.70 & 264 & 657.07 & 53 & 13 & 591.07 & 5.80 \\
\hline 27 & $\mathrm{C} 2$ & 601.70 & 132 & 616.01 & 53 & 13 & 550.01 & 6.62 \\
\hline 28 & D2 & 601.70 & 0 & 601.70 & 53 & 13 & 535.70 & 6.95 \\
\hline 29 & E2 & 601.70 & 132 & 616.01 & 53 & 13 & 550.01 & 6.62 \\
\hline 30 & $\mathrm{~F} 2$ & 601.70 & 264 & 657.07 & 53 & 13 & 591.07 & 5.80 \\
\hline 31 & A1 & 734.30 & 396 & 834.27 & 53 & 13 & 768.27 & 3.54 \\
\hline 32 & B1 & 734.30 & 264 & 780.32 & 53 & 13 & 714.32 & 4.06 \\
\hline 33 & $\mathrm{C} 1$ & 734.30 & 132 & 746.07 & 53 & 13 & 680.07 & 4.46 \\
\hline 34 & D1 & 734.30 & 0 & 734.30 & 53 & 13 & 668.30 & 4.61 \\
\hline 35 & E1 & 734.30 & 132 & 746.07 & 53 & 13 & 680.07 & 4.46 \\
\hline 36 & $\mathrm{~F} 1$ & 734.30 & 264 & 780.32 & 53 & 13 & 714.32 & 4.06 \\
\hline & & & ose ra & at measurer & ent point $\mathrm{P}$ & & & 942.22 \\
\hline
\end{tabular}

